\title{
Therapy of Cinnamon Decoction using Honey in Reducing Gout
}

\author{
Yeti Nurhayati'), Tresia Umarianti²) \\ ${ }^{1)}$ Nursery Program, School of Health Sciences Kusuma Husada, Surakarta \\ 2)Diploma III of Midwifery, School of Health Sciences Kusuma Husada, Surakarta
}

\begin{abstract}
Background: Gout is an antioxidant, the final product that is produced from the metabolism/ breakdown of purines, but if in excessive amounts in the blood, it will experience crystallization and can cause gout. Giving cinnamon extract to male white rats with hyperuricemia has the effect of reducing uric acid levels, because the extract of cinnamon contains Polyphenols namely Sinamldehid which is high enough (68.65\%) to be a source of antioxidant compounds which can inhibit Xanthine Oxidase Enzine. This study aimed to analyze the therapy of dekokta cinnamon with honey to reduce uric acid for people with gout.
\end{abstract}

Subjects and Method: This was a quasi experiment with pre and post-test design. The study was conducted in Gambirsari Community Health Center, Kadipiro Subdistrict, Mojosongo, Surakarta, Central Java, in May 2018. A sample of of 50 people with gout sufferers were selected by quota sampling and divided into 2 groups. The treatment group of 25 people received cinnamon decoction with honey with a concentration of $15 \%$. The therapy was carried out for 1 week with a dose of once a day. In the control group, Allopurinol $100 \mathrm{mg}$ was given for 1 week, with a dose of once a day. The data were analyzed by Wilcoxon and Mann-Whitney est.

Results: Uric acid in decoction cinnamon with honey group was lower than in control group and it was statistically significant $(\mathrm{p}=0.023)$.

Conclusion: Decoction cinnamon with honey can reduce uric acid level among gout patients.

Keywords: cinnamon, decoction, honey, gout

Correspondence:

Yeti Nurhayati. Nursery Program, School of Health Sciences Kusuma Husada, Surakarta, Central Java. Email: yeti_nurhayati234@yahoo.com

\section{BACKGROUND}

Uric Acid is the final product or waste product produced from the metabolism/ breakdown of purines. Gout is also an antioxidant from humans and animals, but if in excessive amounts in the blood, it will experience crystallization and can cause gout. Gout has a role as an antioxidant if the levels are not excessive in the blood, but if the levels are excessive, uric acid will act as a pro-oxidant (McCrudden, 2000).

The previous study was conducted by Tukiyo et al. (2014) on the test of the effect of cinnamon ethanol extract (Cinnamomum Burmanii) on male white rats (Rattus
Novergicus), the results showed that uric acid levels in the blood of male white rats decreased by $64.33 \%$ with cinnamon extract at a concentration of $15 \%$. According to Winda (2014) showed that the administration of cinnamon extract has the effect of reducing uric acid levels in blood in hyperuricemic rats, because the cinnamon extract contains high Polyphenols namely Sinamldehid (68.65\%) become a source of antioxidant compounds so that it can inhibit Xanthine Oxidase Enzine.

Cinnamomi Burmannii Cortex is a stem bark of Cinnamomun Burmannii Nees ex Bl., Member of the tribe of Lauraceae 
(BPOM RI, 2010). According to Shekar et al, in cinnamon (Cinnamomum burmanniNees ex Bl.), there are chemical compounds in the form of phenols, terpenoids and saponins which are sources of antioxidants. Besides that, cinnamon is also known as one of the plants that contain synamaldehyde compounds. Sinamaldehyde is an aldehyde derivative compound which is also included in the class of polyphenolate compounds that have antioxidant properties and sunscreens that are responsible for inhibiting free radical activity (Shekar et al., 2012).

The human body provides 85 percent of purine compounds for daily needs, this means that the need for purines from food is only around 15 percent. Foods that contain high purine substances will be converted to gout. Hyperuricemia can form uric acid crystals/kidney stones which will form a blockage in the ureter. Some causes of increased uric acid were because of several things, including certain diseases such as goud, Leschnyhan syndrome, endogenous nucleic acid metabolism, cancer, abnormal levels of erythrocytes in the blood due to destruction of red blood cells, polycythemia, pernicious anemia, leukemia, genetic disorders purine metabolism, metabolic disorders congenital gout (increased endogenous uric acid synthesis), alcoholism that increases lacticidemia, hypertriglyceridemia, impaired renal function and obesity, ketotic acidosis, acidosislactate, ketoacidosis, lacticidosis, and psoriasis. Normal uric acid levels in the blood are for women 2.0 $6 \mathrm{mg} / \mathrm{dl}$ and for men $2.1-7 \mathrm{mg} / \mathrm{dl}$. A high purine diet is thought to be the cause of an increase in uric acid levels which is at risk for hyperuresemia (Lina and Setiyono, 2014).

\section{SUBJECT AND METHOD \\ 1. Study Design}

The study was carried out by quasi experiment with pre and posttest design. A sample of 50 gout patients was selected for this study by quota sampling and divided into 2 groups. Each group consisted of 25 patients.

\section{Population and samples}

The study was conducted in the working area of the Gambirsari Health Center, Kadipiro Village, Mojosongo Surakarta. The data collection was carried out in May 2018. The treatment group of 25 people received cinnamon dekokta with honey with a concentration of $15 \%$, the therapy was carried out for 1 week with a dose of once a day. In the control group, Allopurinol $100 \mathrm{mg}$ was given for 1 week, with a dose of once a day.

\section{Study Instrument}

Decocta making was done by heating 15 grams of cinnamon simplicia with water as much as $100 \mathrm{cc}$ in a pan with a temperature of $90^{\circ} \mathrm{C}$ for 30 minutes. Strain with a flannel cloth and let stand until warm, then mixed with 1 tablespoon of honey and then it is ready to consume. Therapy is carried out for 1 week at a dose of once a day. In the control group, Allopurinol $100 \mathrm{mg}$ was given for 1 week, with a dose of 1 time a day. The data were analyzed by Wilcoxon and Mann Whitney test.

\section{RESULTS}

\section{Descriptive Analysis}

Respondents in this study were 50 people, where the average age in the treatment group was 57 years and in the control group is 51.16 years. Minimum age in the treatment group was 41 years and a maximum of 72 years, while in the control group a minimum age of 35 years and a maximum of 85 years (Table 1 ). 
Table 1. Age of study subjects

\begin{tabular}{lcccccc}
\hline \multicolumn{1}{c}{ Characteristics } & N & Mean & Median & SD & Min. & Max. \\
\hline Treatment group & 25 & 57.00 & 57.00 & 7.59 & 41 & 72 \\
Control group & 25 & 51.16 & 47.00 & 13.83 & 35 & 85 \\
\hline
\end{tabular}

\section{Frequency distribution}

From Table 2, it can be concluded that the majority of respondents from both groups were women with a percentage of $76 \%$. While for the type of work in the treatment

Table 2. Frequency distribution

\begin{tabular}{lcccc}
\hline Characteristics & \multicolumn{2}{c}{ Treatment } & \multicolumn{2}{c}{ Control } \\
\cline { 2 - 5 } & n & \% & n & \% \\
\hline Gender & 6 & 6 & 24 & 24 \\
Male & 19 & 19 & 76 & 76 \\
Female & & & & \\
Employment & 16 & 64 & 10 & 40 \\
Housewives & 5 & 20 & 10 & 40 \\
Entrepreneur & 3 & 12 & 5 & 20 \\
Private employees & 1 & 4 & & \\
Retired & & & & \\
\hline
\end{tabular}

\section{Bivariate Analysis}

In the treatment group where the treatment group received cinnamon decoction therapy with honey. The results showed that in the pre-intervention mean value of uric acid was 8.6 , min 6.2 and max. 19.8. While in post intervention the mean were 6.0, min 2.0 and $\max 11.5$. with $\mathrm{p}=0.001$.

Then in the control group, where the respondents received Allopurinol $100 \mathrm{mg}$ for 1 week, with a dose of 1 time a day, the results of the pre intervention showed that group the majority of housewives were $64 \%$, and in the control group of housewives were comparable with entrepreneurs, which were $40 \%$ for each.

Table 3.Wilcoxon statistical test results

\begin{tabular}{|c|c|c|c|c|}
\hline \multirow{3}{*}{ Uric acid } & \multicolumn{4}{|c|}{ Group } \\
\hline & \multicolumn{2}{|c|}{ Treatment } & \multicolumn{2}{|c|}{ Control } \\
\hline & Pre & Post & Pre & Post \\
\hline $\mathrm{n}$ & 25 & 25 & 25 & 25 \\
\hline Mean & 8.69 & 6.04 & 8.02 & 6.59 \\
\hline Median & 7.90 & 5.80 & 7.70 & 6.80 \\
\hline $\mathrm{SD}$ & 2.82 & 1.75 & 1.19 & 0.96 \\
\hline Minimum & 6.2 & 2.0 & 6.2 & 4.2 \\
\hline Maximum & 19.8 & 11.5 & 11.6 & 8.4 \\
\hline $\mathrm{p}$ & \multicolumn{2}{|c|}{0.001} & \multicolumn{2}{|c|}{$<0.001$} \\
\hline
\end{tabular}


Indonesian Journal of Medicine (2019), 4(1): 35-39

https://doi.org/10.26911/theijmed.2019.04.01.06

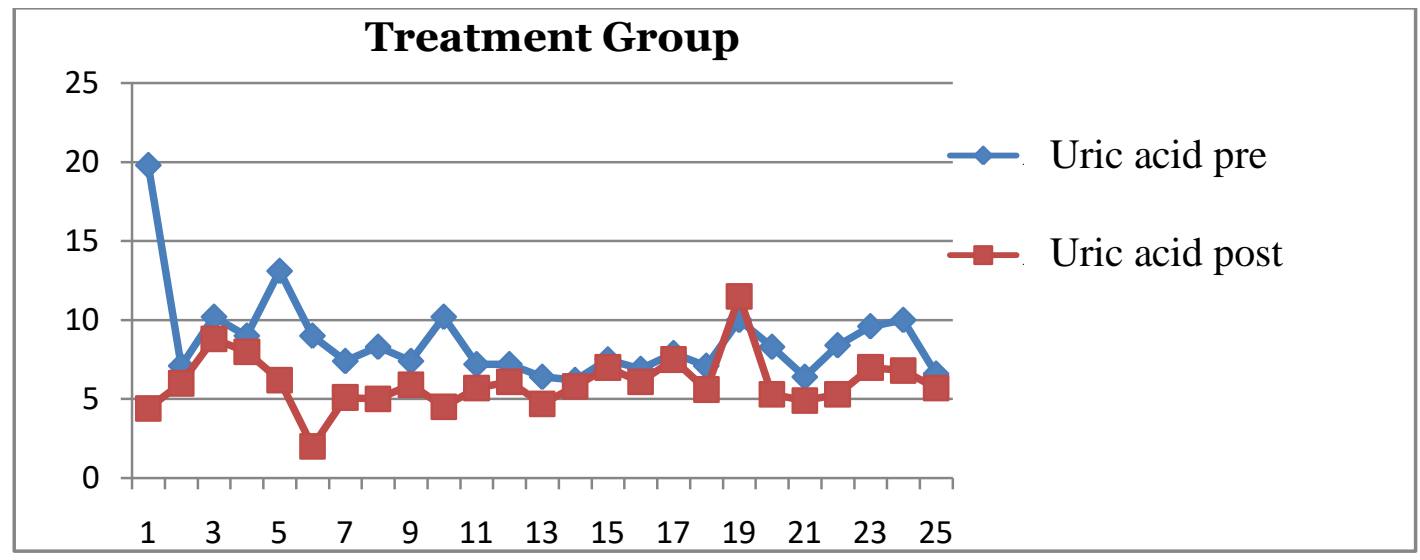

Figure 1. Diagram of Treatment Group

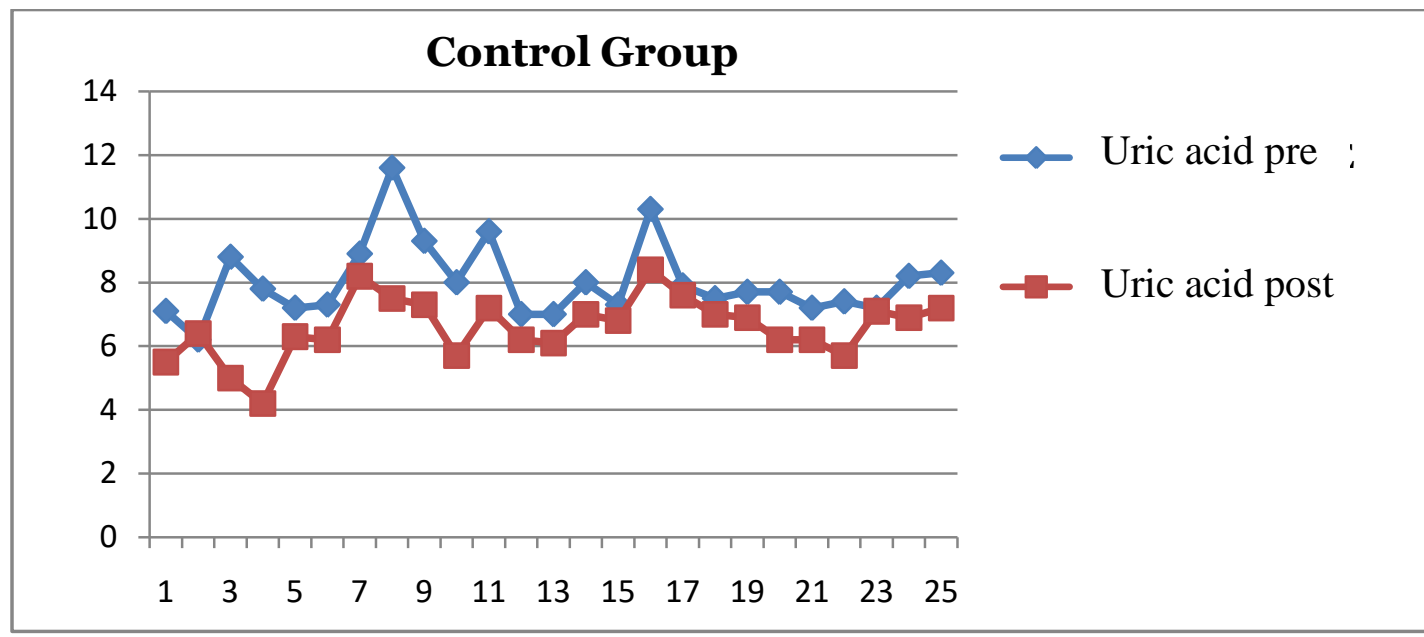

Figure 2. Diagram of Control Group

Table 4. Mann Whitney statistical test results

\begin{tabular}{lcccccc}
\hline \multicolumn{1}{c}{ Uric acid in both groups } & N & Mean & SD & Min. & Max. & p \\
\hline Pre & 50 & 8.35 & 2.17 & 6.2 & 19.8 & 0.749 \\
Post & 50 & 6.31 & 1.43 & 2.0 & 11.5 & 0.023 \\
\hline
\end{tabular}

\section{DISCUSSION}

The basis of this study was a previous study conducted by Tukiyo (2014) which conducted a study on the effects of antiuricemia of ethanol extract of cinnamon (Cinnamomum burmanii) on male white rats (Rattus novergicus) previously induced by potassium bromate. In his study using maceration extraction method, 96\% ethanol solvent, soaking the sample for 3 days to get cinnamon extract. The test animals used were healthy male white rats with a body weight of 100-200 grams, 15 rats and divi- ded into 5 treatment groups, each group consisted of 3 rats. Tukiyo uses different concentrations of cinnamon extract, namely $5 \%, 10 \%$, and $15 \%$. Of the three differences in concentration, the most effective way to reduce uric acid was $15 \%$ (Tukiyo, 2014).

This study did not involve BMI in respondents, so the concentration used $15 \%$ given to respondents was not classified based on BMI. In addition to the effects of dekokta cinnamon, Honey was a material that contained high anti-oxidants. According to Ensminer et al. in Chayati and Mila- 
diyah (2014), it was stated that the antioxidant properties in honey originated from the components of flavonoids, phenolics, vitamin $\mathrm{C}$, amino acids, enzymes, catalase and others (Chayati and Miladiyah, 2014).

Respondents in this study were not in the condition of a doctor's supervision or in a condition that had a complex disease. Khanna et al. (2012) stated that the initial dose of allopurinol given to patients should be no more than $100 \mathrm{mg}$ per day, this dose can be reduced if Chronic Kidney Disease (CKD) was obtained, but maintenance can be given with $300 \mathrm{mg}$ per day even if the patient has CKD. It was recommended to increase the maintenance dose of Allopurinol every 2 to 5 weeks to get an effective dose for people with gout arthritis, for this purpose it was necessary to monitor uric acid levels every 2 to 5 weeks during titration of Allopurinol (Khanna et al, 2012).

\section{ACKNOWLEDGEMENT}

With the implementation of this research, the author would like to thank to: Directorate of Research and Community Service, Directorate General of Strengthening Research and Development at the Ministry of Research, Technology and Higher Education which has provided research grants for the 2018 budget year.

\section{REFERENCES}

Chayati I, Miladiyah I (2014). Kandungan komponen fenolat, kadar fenolat total, dan aktivitas antioksidan madu dari beberapa daerah di Jawa dan Sumatera. Jurnal Media Gizi Masyarakat Indonesia, 6 (1): 11-24.

Khanna et al. (2012). Guidelines for management of gout. Part 1: Systematic Nonpharmacologic and Pharmacologic Therapeutic Approaches to Hyperuricemia, American College of Rheumatology. 64(10): 1431-1446.

Lina N, Setiyono A (2014). Analisis kebiasaan makan yang menyebabkan peningkatan kadar asam urat. Jurnal Kesehatan Komunitas Indonesia. 10.

McCrudden FH (2000). Uric acid: The chemistry, physiology and pathology of uric acid and the physiologically important purin bodies, with a discussion of the metabolism in gout.

Tukiyo IK, Hasan H, Mustapa MA (2014). Uji efek antiuresemia ekstrak etanol kayu manis (Cinnamomum Burmanii) pada tikus putih jantan (Rattus Novergicus). kim.ung.ac.id/index.php/KIMFIKK/article/download/11084 /10957.

Shekar M, et al. (2012). Evaluation of in vitro antioxidant property and radio protective effect of the constituent medicinal plants of a herbal sunscreen formulations. International Journal of Pharmaceutical Frontier Research (IJPFR). 2(2): 5 . 